DOI: $10.31168 / 0459-6.13$

А. Г. Кречлер (Вена, Австрия)

\title{
История славян в «Славяносербских хрониках» Георгия Бранковича
}

Для исследования текстового наследия поздней Православной Славии и процессов перехода к культурной парадигме Нового времени нами был разработан интердисциплинарный подход (Kretschmer 1989; 1998), при котором рассматриваются все характеристики конкретного текста лингвистические, текстуальные, культурологические, социокультурные и этнолингвистические. Это позволяет реконструировать не только язык, но и сознание человека и общества, их видение мира, ср. (Кречмер 2012; Kretschmer 2009). Корпус представлен частной перепиской поздней Московской Руси и петровского времени, ср. (Кречмер 2009; 2018), «Славяносербскими хрониками» (ср. [Бранковић 2008; 2011]) и образцами славяносербской письменности (ок. 17601850 гг.; ср. [Кречмер 2007; 2008; Kretschmer 2012a, 2012b]).

Здесь будут на материале историографического труда Георгия Бранковича (ок. 1645-1711) показаны представления сербов на рубеже XVII-XVIII вв. о происхождении славян, их этно- и глоттонимах. $\mathcal{K}$ личности и труду Бранковича в полной мере можно отнести высказывание А. А. Алексеева о том, что «историческая действительность не имеет перерывов» и что «новый период начинают те же люди и те же тексты, которые завершают старый» (Алексеев 1993: 240). Тематический и временной охват «Хроник» весьма широк от эпохи раннего христианства и истории Византии и до событий сербской истории конца XVII в. В них наряду с систематической презентацией истории сербов и их соседей немало внимания уделяется истории раннего христианства, древней истории славян, славянскому этно- и глоттогенезу.

Бранкович широко опирается на авторитетные источники, от Античности и до современных ему авторов, представ- 
ляет разные точки зрения на определенные темы и вопросы, оставаясь практически всегда объективным хронистом. Безусловно, он не был профессиональным историком, труд его во многом основан на компиляции. Но следует учитывать глобальный культурный контекст, в котором формировался автор «Хроник». Письменная культура Православной Славии была почти полностью сакральной, светская письменность, наука представлены в ней лишь маргинально. Секуляризация культуры начинается поздно и с большим временнь́ім отрывом в разных частях этого культурного ареала.

Автор «Хроник» был широко образованным человеком. Сходный уровень знаний в рамках Православной Славии его времени можно найти, видимо, лишь у восточнославянских книжников Великого княжества Литовского и Речи Посполитой. И в том и в другом случае речь идет о православном славянском миноритарном социуме в мажоритарном европейском культурном окружении в ситуации продолжительных языковых, этнических, конфессиональных и культурных контактов.

Как видел историю славян, их языков, их расселения в Европе ученый серб в конце XVII в., будет показано на примере нескольких отрывков из первой книги «Хроник» ${ }^{1}$.

$(\mathrm{I} / 8-53)^{2}<\ldots>$ Биондо Флавио < .. > описывая время императоров Аркадия и Гонория, упоминает славян и то, что они впоследствии расширили свои земли, завоевав у римских императоров Мизию, Дакию, Паннонию, Дарданию, Либурнию, Далмацию, Иллирию, Истрию и некоторые другие государства на севере, как, например, Македонию, Фракию, Эпир, Грецию и Италию, и разорили их. <...> Со временем они <..>

1 Примеры приводятся в нашем переводе (и пунктуации) с максимальным приближением к языку и стилю оригинала.

2 Римскими цифрами обозначена соответствующая книга «Хроник», арабскими страница рукописи. В квадратных скобках даются необходимые для лучшего понимания вставки, многоточием обозначены пропущенные фррагменты текста. 
заняли почти половину Европы и часть Азии. В этом славянском народе есть и поныне особенно великие и сильные - те, кого называют русы, волыны, москвы, болгары, роксоланы, как и фрракийцы, сербы, бошняки, карантанцы, хорваты и те, что владеют Далмацией, Иллирией, Истрией и Венгрией и горами. Им в особой степени соответствует имя славян или славных. Есть и такие, которые проживают на море и на островах, их называют вендами, а греки называют их энетами - по свидетельству Аполлония и Ливия. Некоторые считают, что они пришли из Савроматии, другие - что из Пафрлагонии. Проходя через Ливонию и Пруссию, они захватили территории вандалов и там поселились - это те, кого называют венедами или энетами. О них обо всех пишет в своей «Славянской Хронике» Гельмольд. Тех же, кто живет у Немецкого океана, на реках Сале и Эльба (оставшихся и по сей день славянами) немцы называют винде или венды. О разных их разделениях, именах и народах сообщает Видукинд.

$<$..> Суммируя сказанное - славянский народ происходит от самого Иафета, которого греки называют Япетом, сына Ноева, - как о том пишут те, кто описывает историю ляхов и чехов.

$<$...> По свидетельству Меланхтона в 1-й книге его хроники, имя сербы произошло от савроматийского. Под савроматами же подразумеваются все народы, которые проживают в европейских и азиатских степях, где стекаются реки Танаис и Днепр. Они образуют три больших народа - русов или москвалей, ляхов и литовцев - так свидетельствует Георг Хорн в своей истории. <..> А немцы называют сербов сорабы и сорбы и зорбек - все эти народы проживали у Миотийского озера - где и поныне простирается Московская земля до этого Миотийского озера. <...>

Переходим к рассмотрению вопроса о происхождении названий славяне и славные. <..> Об этимологии названия славян - изначально название это происходило от слова, т. е. языка <..>. Когда же они одержали славные победы над Римом и всяческими народами, они стали называть себя славными и продолжают поныне называться этим именем 
славные в западных и северных областях. А в восточных и южных землях они сохраняют имя словесных или словен поскольку язык требует тут сокращения на один звук, что и лучше согласуется с этимологией, чем у греков и у некоторых итальянцев. <..> Они обычно говорят склави и склавины. Мы же <...> по происхождению нашего отечества считаем первичным именем нашим название словесные или словены.

$<. .>$ И так по делам своим они приняли себе славянославное имя от превеликой славы.

$<. .>$ Затем они распространились по Европе и называли себя по-славянски гости, в насмешку над теми, кого они победили и чьи земли завоевали. Этих гостей греки <..> называли скифскими готами, как и римляне. <..> А все эти вышеупомянутые народы были в союзе с болгарами, сербами, фрракийцами и роксоланами и поселились позднее как гости во Фракии, Македонии и во всей Иллирии и подчинили их себе. Также и те славяне, которые населяли савроматийские горы, как гости поселились сначала в Ливонии и Пруссии, а затем те же славянские гости заселили Вандалию <...>.

Подобного рода исследования сохранившегося текстового материала могли бы помочь в реконструкции мировоззренческой парадигмы поздней Православной Славии и ликвидации немалочисленных еще существующих лакун в наших знаниях о ней.

\section{Литература}

Алексеев 1993 - Алексеев А. А. Внутренняя хронология русского литературного языка // Philologia Slavica (к 70-летию академика Н. И. Толстого) / РАН, Отд-ние литературы и языка, Отд-ние истории, Ин-т славяноведения и балканистики; ред. В. Н. Топоров. М.: Наука, 1993. С. 238-244.

Бранковић 2008 - Бранковић $\hbar$. Хронике славеносрпске = Славяносербские хроники / Српска академија наука и уметности приред. А. Кречмер; уред. Н. Стипчевић. Београд: Српска академија наука и уметности (САНУ), 2008. (Критичка издања српских писаца; 7).

Бранковић 2011 - Бранковић Ђ. Хронике славеносрпске. Књ. 2 / Српска академија наука и уметности; приред. А. Кречмер. Београд: Српска 
академија наука и уметности (САНУ), 2011. (Критичка издања српских писаца; 8).

Кречмер 2007 - Кречлер А. Славеносрпска писменост и њено значење за историјску србистику // Шездесет година института за српски језик САНУ. Зборник радова. 1. Београд: Институт за српски језик САНУ, 2007. C. 313-320.

Кречмер 2008 - Кречлер А. Смена культурной парадигмы в зеркале славяносербской письменности // Етнолингвистичка проучавања српског и других словенских језика = Ethnolinguistic explorations of the Serbian and other slavic languages: у част академика Светлане Толстој / уред. П. Пипер, Љ. Раденковић. Београд: Српска акад. наука и уметности, Одб. за савремени српски језик у светлу савремених лингвистичких теорија, 2008. (Српски језик у светлу савремених лингвистичких теорија = The Serbian language in the light of current linguistic theory / Српска акад. наука и уметности, Од-ње језика и књижевности; књ. 3). С. 187-197.

Кречмер 2009 - Кречлиер А. Человек и социум на Руси XVII-XVIII вв. Категория родства в языке и культуре / Ин-т славяноведения РАН; отв. ред. С. М. Толстая. М.: Индрик, 2009. (Б-ка Ин-та славяноведения; 16). С. 36-56.

Кречмер 2012 - Кречлер А. Картина мира Православной Славии накануне Нового времени (на русском и сербском материале) // Этнолингвистика. Ономастика. Этимология. Материалы II Международной научной конференции. Екатеринбург, 8-10 сент. 2012 г. / Уральский гос. ун-т; отв. ред. Е. Л. Березович. Екатеринбург: Изд-во Уральского ун-та, 2012. С. 29-30.

Кречмер 2018 - Кречлер А. Макро- и микромир русского человека поздней Московской Руси (на материале частной переписки) // In honorem: сборник статей к 90-летию А. Е. Супруна / под ред. Е. Н. Руденко, А. А. Кожиновой. Минск: РИВШ, 2018. С. 133-145.

Kretschmer 1989 - Kretschmer A. Zur Methodik der Untersuchung älterer slavischer schriftsprachlicher Texte (am Beispiel des slavenoserbischen Schrifttums). München: Otto Sagner, 1989. (Slavistische Beiträge; Bd. 241).

Kretschmer 1998 - Kretschmer A. Zur Geschichte des Schriftrussischen Privatkorrespondenz des 17. und frühen 18. Jahrhunderts. München: Peter Lang International Academic Publishing Group, 1998. (Specimina Philologiae Slavicae; Suppl.-Bd. 62).

Kretschmer 2009 - Kretschmer A. Человек за письмом (русский человек Петровского времени в частной переписке // Die russische Sprache und Literatur im 18. Jahrhundert: Tradition und Innovation $=$ Pycский язык и литература в XVIII веке: традиция и инновация: 
Gedenkschrift für Gerta Hüttl-Folter / hrsg. von J. Besters-Dilger, F. B. Poljakov. Frankfurt am Main [etc.]: Peter Lang, 2009. (Русская культура в Европе = Russian culture in Europe, vol. 1). S. 267-287.

Kretschmer 2012a - Kretschmer A. Slawenoserbisch als Phänomen der serbischen Sprach- und Kulturgeschichte und der Slavia Orthodoxa // An den Anfängen der serbischen Philologie. «Salo debeloga jera libo azbukoprotres» von Sava Mrkalj (1810-2010) = На почецима српске филологије. «Сало дебелога јера либо азбукопротрес» Саве Мркаља (1810-2010) / hrsg. von G. Ilić Marković, A. Kretschmer, M. Okuka. Frankfurt am Main [etc.]: Peter Lang, 2012. (Philologica Slavica Vindobonensia; Bd. 1). S. 21-47.

Kretschmer 2012b - Kretschmer A. Šta bi bilo da nije bilo Vuka? // An den Anfängen der serbischen Philologie. "Salo debeloga jera libo azbukoprotres» von Sava Mrkalj (1810-2010) = На почецима српске филологије. «Сало дебелога јера либо азбукопротрес» Саве Мркаља (1810-2010) / hrsg. von G. Ilić Marković, A. Kretschmer, M. Okuka. Frankfurt am Main [etc.]: Peter Lang, 2012. (Philologica Slavica Vindobonensia; Bd. 1). S. 281-285.

\section{Slavs and their History in the "Slavoserbian Chronicles" by G. Branković}

This paper deals with the methods and possibilties which older literature can offer for investigations of the worldview reflecting times long passed. Such an approach is presented hier at the example of the "Slavoserbian Chronicles", wrutten by G. Branković about 1700 — with regard to the origin of Slavs an their names.

DOI: $10.31168 / 0459-6.14$

И. В. Вернер (Москва, Россия)

\section{Супин в чешских библейских переводах}

эпохи национального возрождения (вторая половина XIX в.)

Древнечешский супин, унаследованный от общеславянского образования на -tz, имел в отличие от последнего некоторые особенности формообразования и синтаксического 